\title{
Effect of heavy metals on natural populations of bacteria from surface microlayers and subsurface water
}

\author{
Sang-Jong Kim* \\ Institut für Meereskunde an der Universität Kiel, Düsternbrooker Weg 20, D-2300 Kiel, Federal Republic of Germany
}

\begin{abstract}
The effect of the heavy metals copper and cadmium on natural bacterial populations of surface microlayer and subsurface water was investigated. Two parameters, number of colony-forming bacteria and ${ }^{14} \mathrm{C}$-glucose uptake rate, were evaluated. The 2 natural bacterial populations showed different responses to the heavy metals. Results support the existence of autochthonous bacterioneuston populations in the marine environment.
\end{abstract}

Although a large number of metals are essential for growth, some can be harmful for living cells. This is mainly due to the fact that heavy metals form complexes with protein molecules which render them inactive, for example, inactivation of enzymes. Many heavy metals are detrimental to microorganisms even at the low concentrations present in natural waters (Mills \& Colwell 1977). There are also reports on the adaptation of microorganisms to heavy metals (Azam et al. 1977). This phenomenon has important implications for microbial ecology in polluted ecosystems.

Accumulations of bacteria in the surface microlayer have been reviewed by many authors (e.g. Sieburth 1979, Norkrans 1980). Enrichment of toxic substances such as heavy metals in surface microlayers has also been described from various aquatic ecosystems (Baker \& Zeitlin 1972, Lion \& Leckie 1982). Thus, the physiological state of neuston may be considerably affected by toxic substances. The present study attempted to improve understanding of the biological function of neuston in the marine environment, by investigation of the influence of high heavy metal concentrations on natural populations of bacterioneuston.

Seawater was obtained on calm days only from the innermost Kiel Fjord (Baltic Sea, Federal Republic of Germany). Surface microlayer samples were collected with a sterile circular screen $\left(0.1256 \mathrm{~m}^{2}, 16\right.$ mesh, wire diameter $0.35 \mathrm{~mm}$, stainless steel). The thickness of the

\footnotetext{
- Present address: Dept. of Microbiology, College of Natural
} Sciences, Seoul National University, Seoul 151, Korea sampled surface microlayer was about $430 \mu \mathrm{m}$. Sampling from a depth of $1 \mathrm{~m}$ was conducted with a sterile 51 glass bottle. The 2 water samples were filtered through a stainless steel sieve (mesh size $75 \mu \mathrm{m}$ ) prior to use to remove larger zooplankton and detritus.

Experiments to investigate the effects of copper and cadmium on natural bacterial populations were independently undertaken immediately after collection of seawater samples.

The influence of $\mathrm{Cd}$ and $\mathrm{Cu}$ salts was determined on the basis of bacterial survival (number of colony-forming units) and glucose uptake rate. Sterile standard solutions of heavy metals, $\mathrm{Cd}\left(\mathrm{NO}_{3}\right)_{2} \cdot 4 \mathrm{H}_{2} \mathrm{O}$ and $\mathrm{CuCl}_{2} \cdot 2 \mathrm{H}_{2} \mathrm{O}$, were individually mixed with $500 \mathrm{ml}$ of either neuston sample or subsurface sample. Two different $\mathrm{Cd}$ concentrations and a control were tested for each sample. The final concentrations in the sample were 1 and $10 \mathrm{ppb}(\mathrm{w} / \mathrm{v})\left(10 \mathrm{ppb} \mathrm{Cd}=10 \mu \mathrm{g} \mathrm{Cd} \mathrm{l}^{-1}=\right.$ $\left.27.444 \mu \mathrm{g} \mathrm{Cd}\left(\mathrm{NO}_{3}\right)_{2} \cdot 4 \mathrm{H}_{2} \mathrm{Ol}^{-1}\right)$. Two concentrations were similarly tested for $\mathrm{Cu}$ and reflected 10 and $100 \mathrm{ppb}(\mathrm{w} / \mathrm{v})\left(100 \mathrm{ppb} \mathrm{Cu}=100 \mu \mathrm{g} \mathrm{Cu} l^{-1}=268.3 \mu \mathrm{g}\right.$ $\mathrm{CuCl}_{2} \cdot 2 \mathrm{H}_{2} \mathrm{Ol}^{-1}$ ). These concentrations are 10 and 100 times greater than natural concentrations at $2 \mathrm{~m}$ depth in the investigative area (Kremling et al. 1979). The samples were incubated for $24 \mathrm{~h}$ at room temperature and continually shaken. Just prior to the addition of heavy metals, the number of colony-forming units and ${ }^{14} \mathrm{C}$-glucose uptake rate of the bacteria were determined as initial values.

Colony-forming units on 3 parallels of ZoBell agar plates with salinity $17 \%$ were counted after incubation for $14 \mathrm{~d}$. For the determination of glucose uptake rates, $0.2 \mathrm{ml}$ of D-(U-14 C)-glucose solution ( $=2.5 \mu \mathrm{g} \mathrm{C})$ were added to 3 parallel $10 \mathrm{ml}$ samples from each experimental set and were incubated for $1 \mathrm{~h}$ at room temperature. One of the 3 parallels was set up as a control (fixed with $0.05 \mathrm{ml}$ formalin at the start of the incubation) in order to determine the amount of radioactive substances adsorbed. After incubation the samples were fixed with formalin, then filtered 


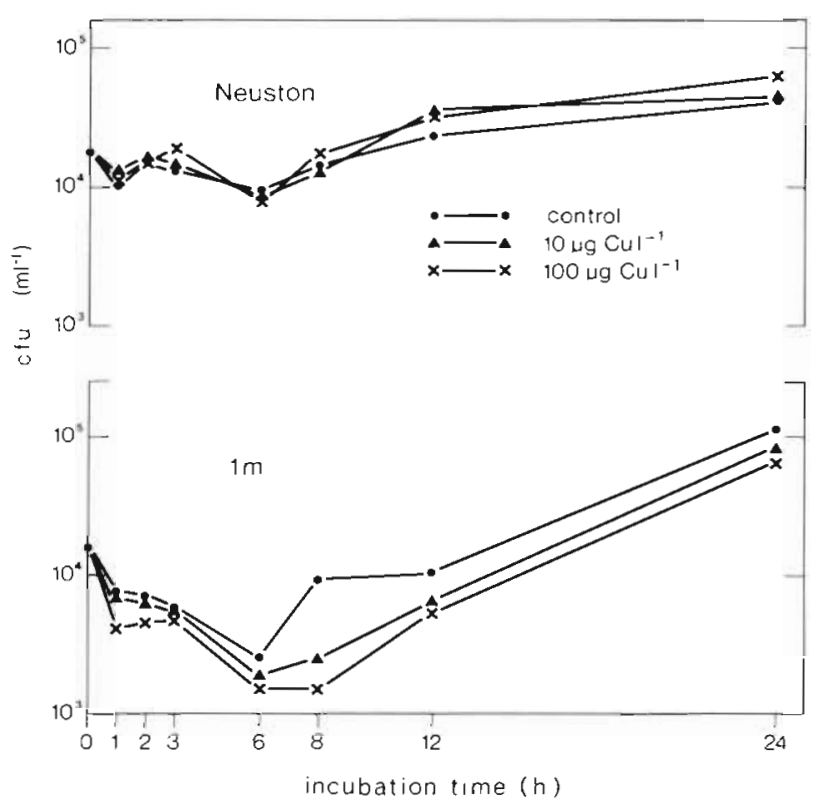

Fig. 1. Effect of copper on the number of colony-forming bacteria

through membrane filters (pore size $0.2 \mu \mathrm{m}$, Sartorius) and rinsed twice with isotonic solution. The filters were put into scintillation vials with $10 \mathrm{ml}$ of Dioxanecocktail and counted in a liquid scintillation counter (Betascint 5000, Berthold and Frieseke) until the statistical counting error was $\pm 1 \%$.

Fig. 1 and 2 present the influence of 2 different concentrations of copper on the number of colonyforming units of bacteria and on the bacterial incorporation of radioactively labelled glucose. The effect of copper on the uptake rate of glucose showed no dis-

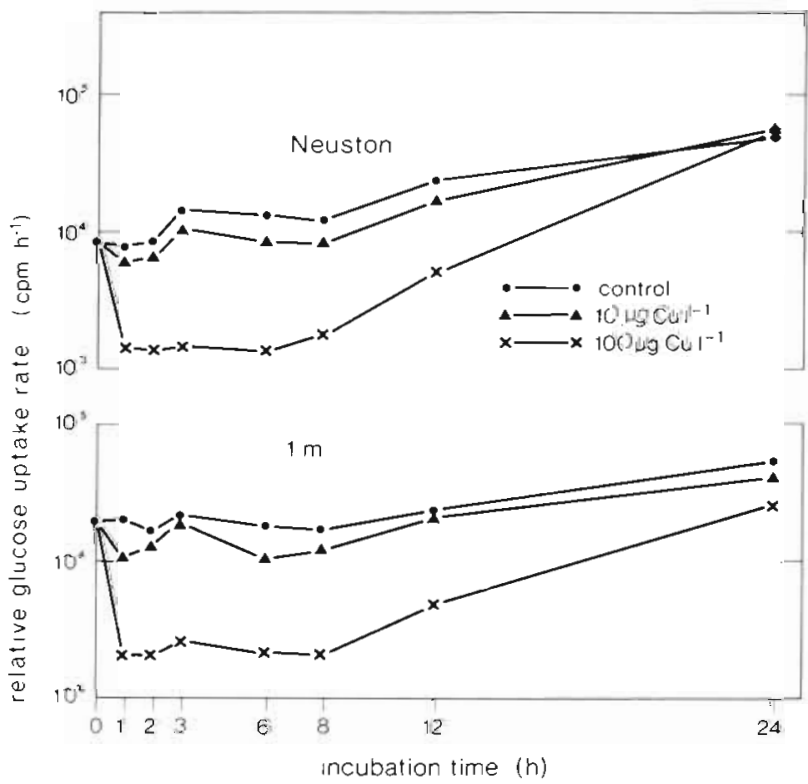

Fig. 2. Effect of copper on the glucose uptake rate of bacteria tinctive differences between the neuston and $1 \mathrm{~m}$ populations, except in the determination after $24 \mathrm{~h}$ incubation (Fig. 2). The inhibition effect on the sample from depth 1 m was still apparent after $24 \mathrm{~h}$, whereas the neuston sample took up glucose in the coppersupplemented water at the same rate as the control. A clearer difference in response was observed from the enumeration of colony-forming units (Fig. 1). In the neuston, the addition of copper salts did not inhibit, but rather slightly stimulated growth. In contrast, in the subsurface water the number of colony-forming units decreased with an increase in copper concentration.

The effects of cadmium on the growth of bacteria are shown in Fig. 3. No inhibition on the growth of neuston was observed at the lower cadmium concentration. At the higher cadmium concentration the inhibition effect on the neuston increased somewhat with increasing incubation time. However, the number of colony-forming units of neuston remained within the same order of magnitude as in the control. In contrast, a considerable difference between the control and the Cd-supplemented sample was noted after $24 \mathrm{~h}$ of incubation for the subsurface water, where the number of colonyforming units was up to 2 orders of magnitude smaller than in the control. With respect to glucose incorporation, no significant inhibition was apparent in neuston and subsurface samples (Fig. 4).

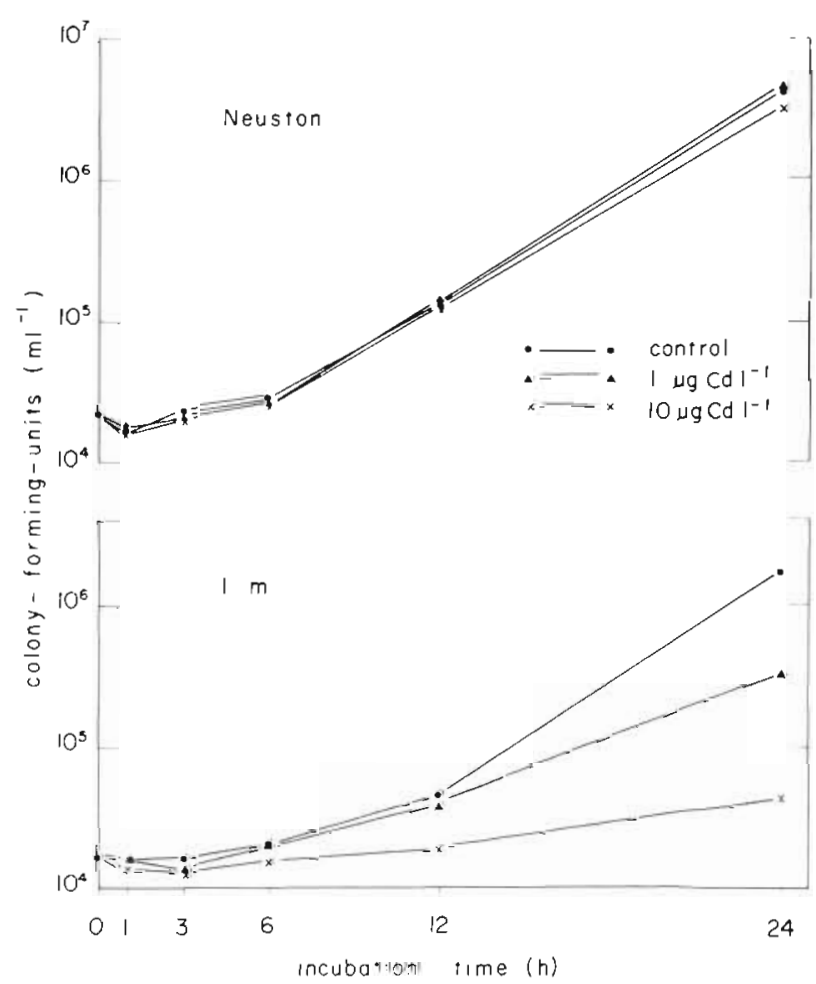

Fig. 3. Effect of cadmium on the number of colony-forming bacteria 


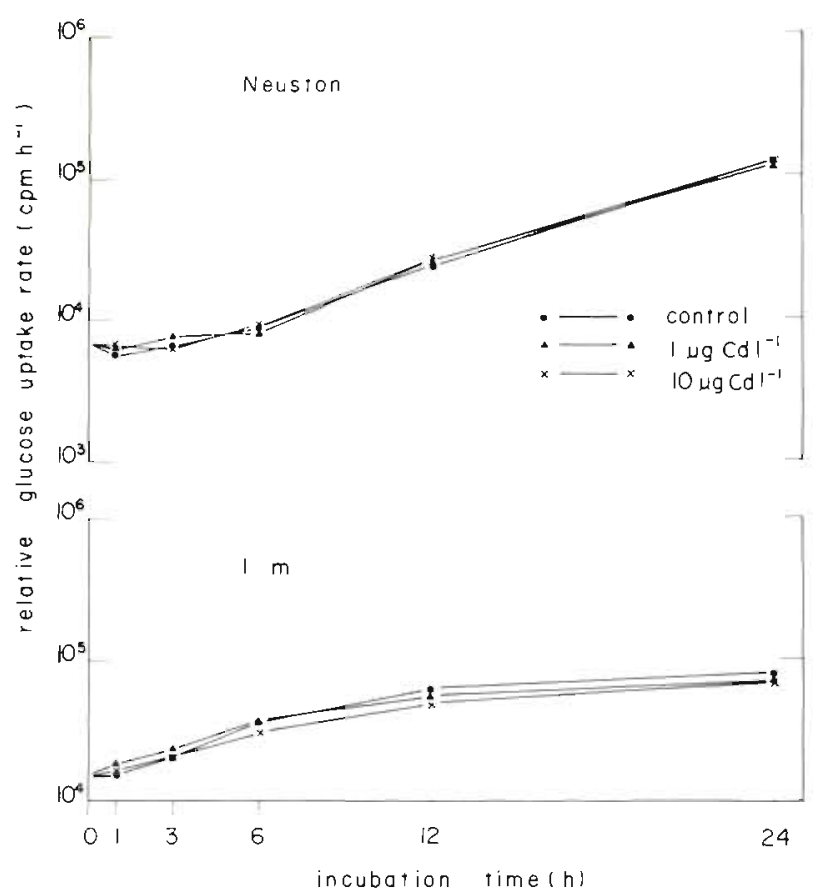

Fig. 4. Effect of cadmium on the glucose uptake rate of bacteria

Seasonal investigations of different microbiological parameters have revealed, as a rule, higher numbers of bacteria in surface microlayers than in subsurface waters (Kim 1983). Chemical components, including pollutants such as heavy metals, are likewise enriched in the surface microlayer (Waldichuk 1982). The enrichment of such toxic substances can exert a considerable influence on the organisms living in this extreme biotope.

It was observed in this investigation of heavy metal influence on natural bacterial populations that the inhibition of growth and activity was stronger in the $1 \mathrm{~m}$ samples than in the neuston. There are several possible explanations for this observation. The concentration-dependent toxicity of a heavy metal can be reduced by various means: through complex-formation with organic compounds (Milanovich \& Wilson 1975 , Benes et al. 1976), through bacterial incorporation and accumulation (Doyle et al. 1975) and through biological metal-transformation (Brunker \& Bott 1974, Holm \& Cox 1975). Thus, in the surface microlayer the toxic effects of heavy metals could possibly be reduced or masked through the formation of complexes of the metals with organic substances, which are enriched in this special biotope.

On the other hand, an adaptation (or selection) of bacteria to heavy metals occurs in the marine environment (Azam et al. 1977). Bacteria originating from metal-containing waters or sediments show a greater tolerance to heavy metals than do those from uncon- taminated environments (Mills \& Colwell 1977). Thorman \& Weyland (1979) thus observed different sensitivities to cadmium and lead in bacteria from an estuary as compared to those from the open ocean. As heavy metals are probably continuously present in the surface microlayer, bacterial adaptations to these substances can be expected, as has been observed in this investigation. It is also possible that the high heavy metal concentrations in surface microlayers, which are 10 to 100 times higher than in the underlying water (Waldichuk 1982), are incorporated or absorbed to a certain degree by bacteria and eventually introduced to the food chain.

The existence of a surface microlayer biotope is only definable under the assumption that it is distinguishable in character and composition from the underlying water. From this viewpoint, the different responses to heavy metals between the bacteria of the 2 investigated water samples support the existence of autochthonous bacterio-neuston populations in the marine environment.

Acknowledgement. This investigation was conducted as part of a Ph.D. thesis at the University of Kiel. I am very grateful to Prof. Dr. G. Rheinheimer for his support and criticism.

\section{LITERATURE CITED}

Azam, F., Vaccaro, R. F., Gillespie, P. A., Moussalli, E. I., Hodson, R. E. (1977). Controlled ecosystem pollution experiment: Effect of mercury on enclosed water columns. II. Marine bacterioplankton. Mar. Sci. Communs 3: 313-329

Baker, D. R., Zeitlin, H. (1972). Metal-ion concentrations in sea-surface microlayer and size-separated atmospheric aerosol samples in Hawaii. J. geophys. Res. 77: 5076-5086

Benes, P., Gjessing, E. T., Steinnes, E. (1976). Interactions between humus and trace elements in fresh water. Water Res. 10: 711-716

Brunker, R. L., Bott, T. L. (1974). Reduction of mercury to the elemental state by a yeast. Appl. Microbiol. 27; 870-873

Doyle, J. J., Marshall, R. J., Pfander, W. H. (1975). Effects of cadmium on the growth and uptake of cadmium by microorganisms. Appl. Microbiol. 29: 562-564

Holm, H. W., Cox, M. F. (1975). Transformation of elemental mercury by bacteria. Appl. Microbiol. 29: 491-494

Kim, S. J. (1983). Vergleichende Untersuchung über die Bakterienpopulation des Neustons und des darunter liegenden Wassers in einem verunreinigten Meeresgebiet. Ph.D. thesis, Univ. of Kiel

Kremling, K., Otto, C., Petersen, H. (1979). SpurenmetallUntersuchungen in den Förden der Kieler Bucht. Berichte Inst. für Meereskunde. Univ. Kiel Nr. 66

Lion, L. W., Leckie, J. O. (1982). Accumulation and transport of $\mathrm{Cd}, \mathrm{Cu}$ and $\mathrm{Pb}$ in an estuarine salt marsh surface microlayer. Limnol. Oceanogr. 27: 111-125

Milanovich, F. P., Wilson, D. W. (1975). Detoxifying effect of yellow substance on $E$. coli in media containing copper. Nature, Lond. 253: 460-461

Mills, A. L., Colwell, R. R. (1977). Microbiological effects of 
metal ions in Chesapeake Bay water and sediment. Bull. environ. Contam. Toxicol. 18: 99-103

Norkrans, B. (1980). Surface microlayers in aquatic environments. In: Alexander, $M$. (ed.) Advances in microbial ecology, Vol 4. Plenum Press, New York, p. 51-85

Sieburth, J. M. (1979). Sea microbes. Oxford Univ. Press, New York
Thormann, D., Weyland, H. (1979). Beziehungen zwischen verschiedenen Brackwasser- und Meeresbakterien und der wachstumshemmenden Wirkung von Cadmium und Blei. Veröff. Inst. Meeresforsch. Bremerhaven 17: 163-188 Waldichuk, M. (1982). Air-sea exchange of pollutants. In: Kullenberg, G. (ed.) Pollutant transfer and transport in the sea, Vol. I. CRC Press, Boca Raton, Florida, p. 177-218

This paper was presented by Professor G. Rheinheimer; it was accepted for printing on July 10, 1985 